\section{Over-tree Microsprinkler Irrigation for Spring Freeze Protection of Peaches}

\author{
Mark Rieger and Stephen C. Myers \\ Department of Horticulture, University of Georgia, Athens, GA 30602
}

Additional index words. Prunus persica, frost, temperature

\begin{abstract}
The feasibility of using an over-tree microsprinkler irrigation system for spring freeze protection of 'Loring' peach trees [Prunus persica (L.) Batsch] was evaluated under a range of meteorological conditions during Winter 1988-89. Microsprinklers were attached to the underside of polyethylene laterals $2.5 \mathrm{~m}$ above ground level and centered over the tree rows. Irrigation rates of $0,27,36$, and 44 liters/hour per tree were tested on trees trained to an open-center habit using microsprinklers that produced a circular wetting pattern. Microsprinkler irrigation maintained average bud temperature above $-2 \mathrm{C}$ and 2 to $5 \mathrm{C}$ above those of nonirrigated trees under calm conditions, but provided no protection under windy conditions. Flower bud temperatures of irrigated trees were similar for 36 and 44 liters'hour ${ }^{-1}$, but were slightly lower for 27 liters'hour $^{-1}$ under conditions typical of spring freezes. Limb breakage due to ice loading was negligible for all application rates, even under advective freeze conditions. Calculated water and energy consumption were reduced by at least $50 \%$ and $\mathbf{8 8 \%}$, respectively, by the microsprinkler system, compared to a typical overhead sprinkler system.
\end{abstract}

Subfreezing temperatures during the blossom period result in greater losses of production for fruit crops than any other environmental or biological hazard in the United States (USDA, 1988). Although several protection methods are available, many are too expensive to be practical, considering the high cost of establishing and managing modern intensive orchard systems. Fruit growers seek low-cost, effective methods of freeze protection as alternatives to orchard heaters, wind machines, or overhead sprinkler irrigation.

Microsprinkler and other microirrigation systems are increasing in popularity with fruit growers due to low costs and water usage. The effectiveness of microsprinkler irrigation for freeze protection has been demonstrated on young citrus trees under a wide range of meteorological conditions (Parsons and Wheaton, 1987; Rieger et al., 1986). Microsprinkler and conventional overhead sprinkler systems provide protection via the same mechanism (i.e., release of sensible and latent heat of fusion of water), but installation and annual costs per unit land area are lower for microsprinklers (Harrison et al., 1983). However, protection

Received for publication 12 June 1989. A contribution of the Univ. of Georgia Agricultural Experiment Station, College Station, Athens. This research was supported by State and Hatch Act funds allocated to the Georgia Experiment Stations and a grant from the Univ. of Georgia Research Foundation: We thank J.L. Chesness for helpful discussion of energy requirement calculations. Mention of trademark name does not imply endorsement by us or the Univ. of Georgia to the exclusion of other similar products. The cost of publishing this paper was defrayed in part by the payment of page charges. Under postal regulations, this paper therefore must be hereby marked advertisement solely to indicate this fact. with microsprinklers is limited to the wetted portion of the canopy (lower 0.5 to $1.0 \mathrm{~m}$ ) and is therefore useful for young trees only, since rnicrosprinklers are normally mounted at ground level (Rieger et al., 1988). The warming effect on the air from microsprinkler irrigation is often negligible or decreases rapidly with height above the zone of application (Buchanan et al., 1982 Rieger et al., 1986).

Recent field trials with a microsprinkler system mounted above mature peach trees showed that microsprinklers provided protection similar to an overhead impact sprin(John et al., 1986). Although the microsprinkler system in this study used $\approx 30 \%$ less water than the impact system, the rate of water application $\left(4.8 \mathrm{~mm} \cdot \mathrm{hr}^{-1}\right)$ was nearly twice that of more typical overhead impact systems. Hence, the microsprinkler system design of John et al. (1986) required more kler system during several radiative freezes by an asterisk. water than normally applied by currently used overhead sprinkler systems $\left(2.5 \mathrm{~mm} \cdot \mathrm{hr}^{-1}\right)$. It is unclear how water application rate and freeze conditions affect the protection afforded by over-tree microsprinklers, since only one application rate was used $\left(4.8 \mathrm{~mm} \cdot \mathrm{hr}^{-1}\right)$, and the system was evaluated only during calm, high-dewpoint conditions.

The objective of our study was to examine the feasibility of using microsprinklers to apply water at rates less than those of typical overhead impact systems (i.e., $<2.5 \mathrm{~mm} \cdot \mathrm{hr}^{-1}$ or 25,380 liters $\cdot \mathrm{ha}^{-1} \cdot \mathrm{hr}$ ) for protection of peach flowers over a range of freeze conditions.

Orchard site and irrigation system. A microsprinkler irrigation system was installed in a 0.4-ha freeze-prone orchard site planted with 3-year-old 'Loring' peach trees on Lovell rootstock. Trees were trained to an open center at $8 \times 4.3-\mathrm{m}$ spacing and were $\approx 2$ $\mathrm{m}$ tall. Water was pumped from a well through a 50-mm-diameter main line that supplied 12.5-mm-diameter polyethylene laterals. Laterals were suspended over the tree rows $\approx 2.5 \mathrm{~m}$ above ground level using a support system consisting of $3.5-\mathrm{m}$ wooden posts and a single 12-gauge (3.0 $\mathrm{mm}$ in diameter) wire. Microsprinklers were centered over each tree and therefore were $4.3 \mathrm{~m}$ apart on laterals.

Hardie Microsprinkler III emitters (Hardie Irrigation, El Cajon, Calif.) were attached to the underside of laterals using $150-\mathrm{mm}$ lengths of 6-mm-diameter flexible tubing to facilitate drainage and keep the emitter oriented properly in case of movement of the lateral tubing. The microsprinklers produced a circular wetted area with application rate highest at the periphery. Emitter flow rates (liters/ hour) were measured by catching water in a graduated cylinder for 1 min on three emitters of each type used. Emitters differed by the size of the orifice in the water flow path only, which allowed for different application rates but similar distribution patterns. Due to the conical distribution pattern, application rates varied from 13 to $16 \mathrm{~mm} \cdot \mathrm{hr}^{-1}$ at 300 $\mathrm{mm}$ below the microsprinkler, to 2.5 to 5.0 $\mathrm{mm} \cdot \mathrm{hr}{ }^{-1}$ at the level of fruiting wood of most trees, to 1.5 to $1.8 \mathrm{~mm} \cdot \mathrm{hr}^{-1}$ at ground level.

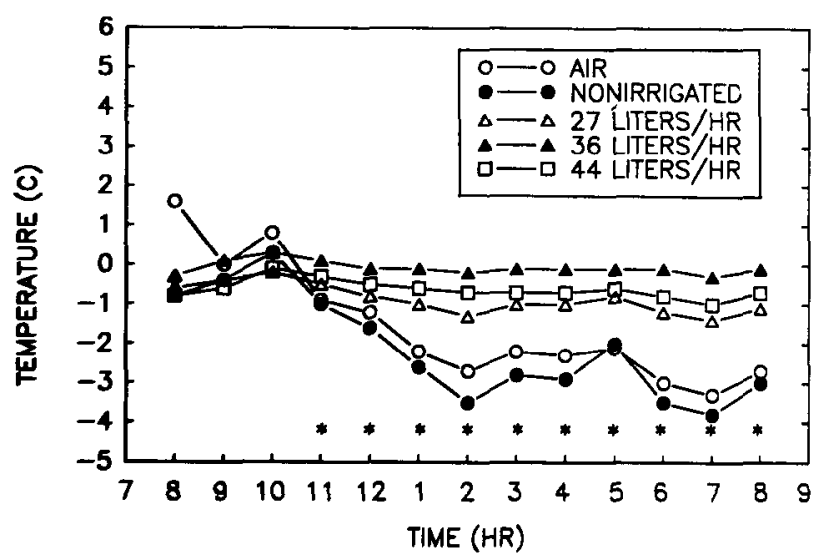

Fig. 1. Air and flower bud temperature of 'Loring' peach trees irrigated with over-tree microsprinklers during radiative freeze conditions of 13-14 Dec. 1988. For irrigated trees, $n=12$; for nonirrigated trees, $\mathrm{n}=8$. Significant differences $(P=0.05)$ among treatments occurred at each hour denoted 


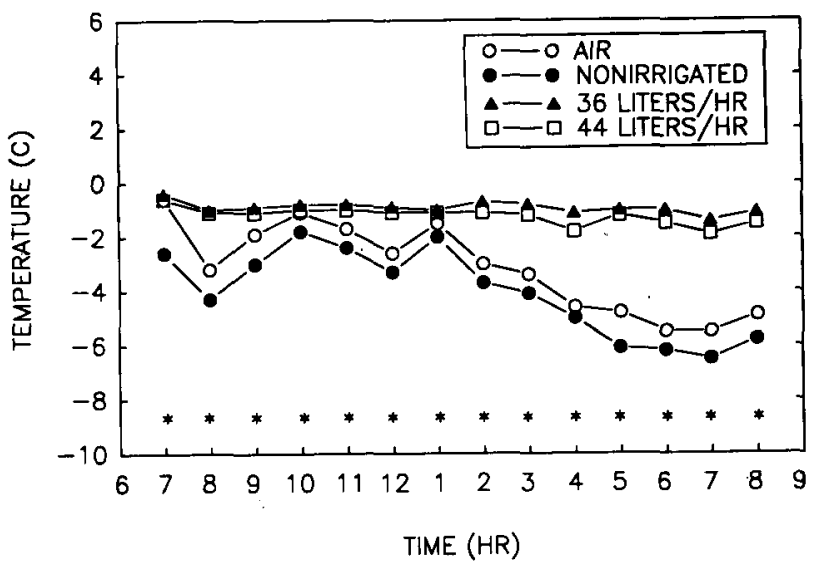

Fig. 2. Air and flower bud temperature of 'Loring' peach trees irrigated with over-tree microsprinklers during radiative freeze conditions of 18-19 Dec. 1988. For irrigated trees, $n=16$; for nonirrigated trees, $\mathrm{n}=8$. Significant differences $(P=0.05)$ between irrigated treatments (collectively) and nonirrigated treatments occurred at each hour denoted by an asterisk.

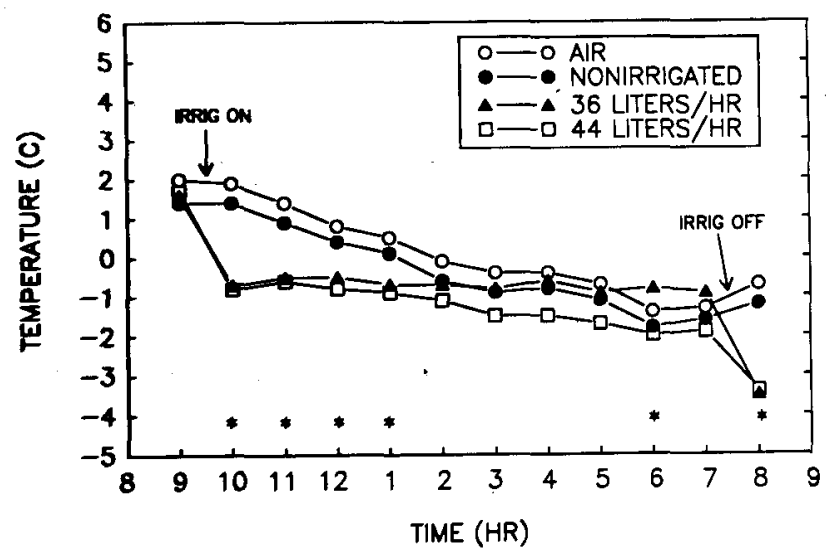

Fig. 3. Air and flower bud temperature of 'Loring' peach trees irrigated with over-tree microsprinklers during advective freeze conditions of 21-22 Jan. 1989. For irrigated trees, $n=16$; for nonirrigated trees, $\mathrm{n}=8$. Significant differences $(\mathrm{P}=0.05)$ between irrigated treatments (collectively) and nonirrigated treatments occurred at each hour denoted by an asterisk. However, at 6:00 am, the 36liters'hr' treatment was significantly different from the 44-liters.hr-' and nonirrigated treatments.

Table 1. Meteorological conditions during over-tree microsprinkler irrigation experiments in a 3-yearold 'Loring' peach orchard.

\begin{tabular}{|c|c|c|c|c|}
\hline $\begin{array}{c}\text { Date } \\
(1988-89) \\
\end{array}$ & $\begin{array}{c}\text { Minimum air } \\
\text { temp } \\
1.2-\mathrm{m} \text { ht } \\
\left({ }^{\circ} \mathrm{C}\right) \\
\end{array}$ & $\begin{array}{c}\text { Average } \\
\text { dewpoint } \\
1.2-\mathrm{m} \mathrm{ht} \\
\left({ }^{\circ} \mathrm{C}\right) \\
\end{array}$ & $\begin{array}{l}\text { Wind } \\
\text { speed } \\
3.0-\mathrm{m} \mathrm{ht} \\
\left(\mathrm{m} \cdot \mathrm{s}^{-1}\right)\end{array}$ & $\begin{array}{c}\quad \text { Net } \\
\text { radiation } \\
1.2-\mathrm{m} \mathrm{ht} \\
\left(\mathrm{W} \cdot \mathrm{m}^{-1}\right)\end{array}$ \\
\hline $\begin{array}{l}\text { 13-14 Dec. } \\
\text { 18-19 Dec. } \\
\text { 21-22 Jan. } \\
\text { 10-11 Feb. } \\
\text { 8-9 Mar. }\end{array}$ & $\begin{array}{l}-3.3 \\
-5.5 \\
-1.6 \\
-2.8 \\
-2.2\end{array}$ & $\begin{array}{c}-18.3 \\
-5.7 \\
-9.5 \\
-8.6 \\
-1.9\end{array}$ & $\begin{array}{l}0.0 \text { to } 1.0 \\
0.0 \text { to } 1.2 \\
1.1 \text { to } 2.9 \\
0.5 \text { to } 2.0 \\
0.0 \text { to } 1.9\end{array}$ & $\begin{array}{l}-15 \text { to }-45 \\
-26 \text { to }-57 \\
-28 \text { to }-53 \\
-45 \text { to }-58 \\
-32 \text { to }-48\end{array}$ \\
\hline
\end{tabular}

Microsprinklers were operated at $68 \mathrm{kPa}$ for calibration and during all freeze events.

The microsprinkler system was operated during five freezes having diverse meteorological characteristics from Dec. 1988 to Mar. 1989 (Table 1). Initially, application rates of 0 (nonirrigated), 27, 36, and 44 liters $/ \mathrm{hr}$ per tree were used. However, the 27-liters $\cdot \mathrm{hr}^{-1}$ rate was discontinued after the 13-14 Dec. freeze to allow for increased replication of temperature measurements in the remaining treatments. The experimental design was completely randomized, with three (13-14 Dec.) or four (all other freeze dates) experimental units per treatment, each consisting of three consecutive trees in a row; bud tem- any microclimate modification that may have occurred was ineffective in altering bud temperatures in unwetted zones of the tree. Average bud temperature for irrigated treatments was derived from a total of 12 thermocouple values from three replicates on 13-14 Dec. and 16 thermocouple values from four replicates per treatment for all other freezes. Four flower bud temperatures on each of only two nonirrigated trees were measured, since variability in bud temperature was lower without irrigation $(\mathrm{SD} \pm 0.3 \mathrm{C})$ than with (see below).

Air temperature was measured with a shielded thermocouple at an instrument shelter within the orchard. Relative humidity and net radiation were measured in the canopy of a nonirrigated tree near the instrument shelter with an Omega HX-41 humidity probe (Omega Engineering, Stamford, Corm.) and a Fritschen-type net radio-meter (Radiation Energy Balance Systems, Seattle), respectively. Data were logged as 15 -min averages using a Campbell CR-7 datalogger (Campbell Scientific, Logan, Utah) with an execution interval of 10 see; hence, each value used in subsequent statistical analyses was the average of 90 individual measurements taken over $15 \mathrm{~min}$. Standard deviations for bud temperature data generally were \pm 0.5 to $1.5 \mathrm{C}$ and were similar among irrigated treatments, regardless of application rate.

Blossom injury. Ovary mortality was estimated on the afternoon of 10 Mar. 1989 to assess potential crop loss from the 8-9 Mar. freeze when trees were nearly in full bloom. Thirty flower ovaries were taken from the wetted region of the canopy and examined for viability from each of three trees in the 0-, 36-, and 44-1iters $\cdot \mathrm{hr}^{-1}$ treatments. Ovaries were rated alive if green and turgid, and dead if blackened and desiccated.

Water and energy use comparison. Water and energy use on a per hectare basis were calculated from measured values of flow rate and pressure from the microsprinkler system. These were compared to water and energy use calculations for a typical overhead impact system supplying $2.5 \mathrm{~mm} \cdot \mathrm{hr}^{-1}$ at 272 $\mathrm{kPa}$. Energy use (Watts-ha-1) was calculated as: Energy $=\mathrm{Q} \times \mathrm{TDJ}-\mathrm{U}\left(6.12 \times \mathrm{E}_{\mathrm{p}}\right)$, where $\mathrm{Q}$ is the flow discharge (liters $\cdot \mathrm{min}^{-1} \cdot \mathrm{ha}^{-1}$ ), TDH is the total dynamic head (m), $\mathrm{E}_{\mathrm{p}}$ is the pump efficiency (assumed $=0.75$ ), and 6.12 is a coefficient to convert units (James, 1988). The TDH was assumed equal to the operating pressure, which assumes that delivery losses and other minor head loss components were the same for both systems.

Data were analyzed by regression of bud temperature and irrigation rate at each hour of the night on each freeze date. Individual contrasts were run to examine the relationships among treatments for times showing significant linear or quadratic regression coefficients.

Flower buds were dormant during all but the 8-9 Mar. freeze and, therefore, capable of withstanding lower temperatures than those that occurred. However, it is possible to assess the potential injury to open flowers for each freeze date based on published values 


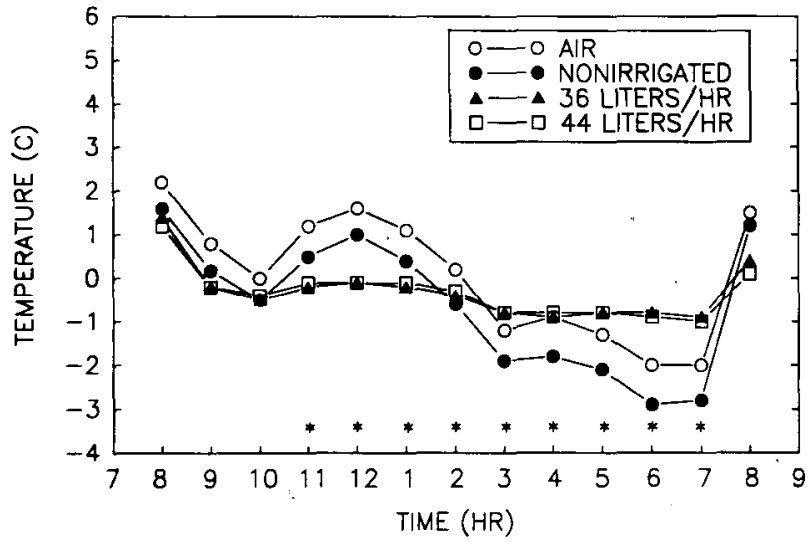

Fig. 4. Air and flower bud temperature of 'Loring' peach trees irrigated with over-tree microsprinklers during advective freeze conditions of 8-9 Mar. 1989. For irrigated trees, $\mathrm{n}=16$; for nonirrigated trees, $\mathrm{n}=8$. Significant differences $(P=0.05)$ between irrigated treatments (collectively) and nonirrigated treatments' occurred at each hour denoted by an asterisk.

of killing points for peach flowers in full bloom. The temperature at which $10 \%$ flower bud mortality occurs is reported to be $-2.8 \mathrm{C}$, and that causing $90 \%$ mortality, $-4.4 \mathrm{C}$ (Ballard et al., 1971).

The 13-14 Dec. freeze event was typical of spring frost conditions that frequently cause crop losses. Regardless of application rate, average flower bud temperatures of irrigated trees were maintained above potentially damaging levels $(-2.8 \mathrm{C})$, while nonirrigated bud temperatures fell to $-3.8 \mathrm{C}$ (Fig. $1)$. Only two of the 12 buds in the $27-$ liters $\cdot \mathrm{hr}^{-1}$ treatment registered below $-2.8 \mathrm{C}$, whereas none of the buds in the 36- or 44liters $\cdot \mathrm{hr}^{-1}$ treatment were below this value at any time. During all but the first $3 \mathrm{hr}$ of the freeze, contrasts showed that 36 liters $\cdot \mathrm{hr}^{-1}$ produced higher bud temperatures than 27 liters $\cdot \mathrm{hr}^{-1}$, although 44 liters $\cdot \mathrm{hr}^{-1}$ did not differ from either of these treatments.

Results from the 18-19 Dec. freeze were similar to those of 13-14 Dec., except that 27 liters.hr' had been omitted (Fig. 2). Average bud temperatures for the 36- and 44liters $\cdot \mathrm{hr}^{-1}$ treatments were maintained above potentially damaging levels and were significantly higher than those of nonirrigated buds throughout the night. Three to four of the 16 buds in each irrigated treatment registered temperatures below $-2.8 \mathrm{C}$ toward the end of the night, but bud temperatures were not below the $90 \%$ killing threshold of $-4.4 \mathrm{C}$ at any time. Therefore, it is possible that a small percentage $(<25 \%)$ of the buds on irrigated trees could have been killed, although it is unclear if this would have affected yield, since peach trees require extensive blossom or fruit thinning to produce fruit of marketable size. Since nonirrigated bud temperatures ranged from -6.6 to -7.1 , a complete' loss of crop might have resulted had this freeze occurred during or after full bloom.

Bud temperatures of irrigated trees were equal to or below those of nonirrigated trees during the advective freezes of 21-22 Jan. (Fig. 3) and 10-11 Feb. (data not shown). Bud temperatures for the 36- and 44-liters $\cdot \mathrm{hr}^{-1}$ treatments decreased rapidly and approached the wet bulb temperature on 2122 Jan. when irrigation commenced, and remained significantly lower than nonirrigated bud temperatures for the first $4 \mathrm{hr}$ of the night. During the remainder of the night, bud temperatures of irrigated trees did not differ from those of nonirrigated trees, except at 6:00 AM, when bud temperatures for the 36liters $\cdot \mathrm{hr}^{-1}$ rate were significantly higher than those of the nonirrigated and 44-liters.hrtreatments. It is unclear why bud temperatures differed between 36 and 44 liters $\mathrm{hr}^{-1}$ at this time and not on any of the 60 other occasions analyzed in this study.

Discontinuing irrigation before sunrise, while windspeed was 2.4 to $2.9 \mathrm{~m} \cdot \mathrm{s}^{-1}$, caused irrigated bud temperatures to decrease rapidly to the wet bulb temperature. Microsprinkler irrigation at the rates tested in this study provided no protection and may decrease flower bud temperature compared to nonirrigated trees during freezes with sustained, light (1 to $3 \mathrm{~m} \cdot \mathrm{s}^{-1}$ ) wind. However, wind gusts of $1.2 \mathrm{~m} \cdot \mathrm{s}^{-1}$ on otherwise calm nights (December freezes) did not appear to influence bud temperatures of irrigated trees. Therefore, microsprinkler irrigation does not differ from conventional overhead sprinkler irrigation with respect to efficacy under windy conditions.

The 8-9 Mar. freeze occurred when the trees were at $\approx 75 \%$ full bloom. Windy conditions from 11:00 PM to 2:00 AM elevated nonirrigated bud and air temperatures above those of irrigated trees, but a decrease in windspeed after 2:00 AM allowed nonirrigated bud temperatures to fall 1 to $2 \mathrm{C}$ below those irrigated (Fig. 4). Average ovary mortality on 10 Mar. was $7 \% \pm 6 \%, 18 \% \pm$ $8 \%$, and $10 \% \pm 9 \%$ for 0,36 , and $44 \mathrm{li}-$ ters $\cdot \mathrm{hr}^{-1}$, respectively, and differences were nonsignificant. Flower mortality of $7 \% \pm$ $6 \%$ corresponding to an average bud temperature of $-2.9 \mathrm{C}$ for nonirrigated trees in this study agrees well with the reported $10 \%$ of buds being killed at $-2.8 \mathrm{C}$ (Ballard et al., 1971). However, similar ovary mortality for irrigated trees, which had average bud temperatures no lower than $-1.5 \mathrm{C}$, indicates that the cause of ovary mortality may not have been related to the 8-9 Mar. freeze. All trees required thinning to obtain marketable fruit size.

The efficiency of each application rate, expressed as bud temperature increase above nonirrigated trees per unit water applied per hour $\left({ }^{\circ} \mathrm{C} \cdot\right.$ liter $\left.^{-1} \cdot \mathrm{hr}^{-1}\right)$, was used as a standard of comparison to examine the benefit per unit input for differing irrigation rates. Efficiency was evaluated at the time of lowest air temperature on each date. Efficiency was significantly higher for 36 liters $\cdot h r^{-1}$ than for 44 liters.hr-1 ${ }^{-1}$ for the 18-19 Dec. and 2122 Jan. freezes, but did not differ among rates on other freeze dates. The combined effects of numerically higher bud temperatures and lower application rate for 36 than for 44 liters $\cdot \mathrm{hr}^{-1}$ caused the difference in efficiency values in these two cases. Efficiency ranged from a high of 0.15 for 36 liters $\cdot \mathrm{hr}^{-1}$ on 19 Dec. to a low of -0.002 for 44 liters.hr' on 22 Jan. Generally, efficiency was highest under calm conditions and lowest under windy, low-dewpoint conditions, regardless of application rate. An application rate of 36 liters/hr per tree is the most efficient for protection of peach flower buds under freeze conditions typical of those occurring during the blossom period.

Calculated water and energy use (on a per hectare basis) of the microsprinkler system used in this study were substantially less than for a typical overhead sprinkler system. Water savings for the microsprinkler system were $69 \%, 59 \%$, and $50 \%$ for the $27-, 36-$, and 44-liters.hr-1 rates, respectively, and energy savings were $88 \%$ to $93 \%$, depending on microsprinkler irrigation rate. A doubling of plant density would decrease water savings to $0 \%$ to $38 \%$ (assuming one microsprinkler per tree), but would only decrease energy savings to $75 \%$ to $85 \%$, depending on irrigation rate. Water savings in this study were greater than previously reported for over-tree microsprinklers (John et al., 1986) due to lower application rates per emitter and wider microsprinkler spacings.

Limb breakage from ice-loading was negligible. Only one 40-mm-diameter limb in the entire orchard was broken after the 1314 Dec. freeze. No breakage was noticed on other dates, even though ice thickness was typically 20 to $30 \mathrm{~mm}$ on 1-year-old wood after $\approx 12 \mathrm{hr}$ of irrigation. Because trees were unpruned for all but the 8-9 Mar. freeze, iceloading was greater than would be expected for pruned trees, since more fruiting wood provided a greater surface for ice formation. Hence, it does not appear that limb breakage would be a problem for growers with pruned or unpruned trees under freeze conditions similar to those encountered in this study.

One problem with over-tree microsprinkling is the additional cost of the overhead support system for the lateral irrigation lines. An alternative and potentially less costly arrangement to the overhead support system was tested during the 8-9 Mar. freeze. Microsprinklers were attached to $1.5-\mathrm{m}$ stakes at the center of each of five open-center trees, and water was supplied to microsprinklers via 6-mm-diameter extension tubing from 
polyethylene laterals on the soil surface. Although no bud temperature data were collected, canopy ice distribution was similar for overhead wire-supported and stake-supported microsprinklers. Microsprinkler support systems, water distribution patterns, and application rates may need to be modified from those used in this study to protect trees trained to systems other than open center.

Over-tree microsprinkling appears to provide protection similar to that reported for conventional overhead sprinkler systems (Rieger, 1989) and also possesses the same limitation-lack of effectiveness under windy, low-dewpoint conditions. Microsprinkler application rate at the level of fruiting wood ( 2.5 to $5.0 \mathrm{~mm} \cdot \mathrm{hr}^{-1}$ ) was in close agreement with recommended application rates derived from heat transfer calculations for typical overhead impact systems (Gerber, 1970). The main advantage of over-tree microsprinkling appears to be potential water and energy savings, compared to conventional overhead sprinkler systems. Furthermore, microsprinklers may be more suitable than conventional overhead systems for the application of nutrients, pesticides, and growth regulators, and evaporative cooling for bloom delay or alleviation of heat stress. Multiple uses would help defray the additional cost of the support system. Growers that currently use low-volume irrigation and/or trellis support systems in their- orchards could- easily and economically convert to the over-tree microsprinkler system.

\section{Literature Cited}

Ballard, J. K., E.L. Proebsting, R.B. Tukey, and H. Mills. 1971. Critical temperatures for blossom buds. Wash. State Agr. Ext. Circ. 373.

Buchanan, D. W., F.S. Davies, and D.S. Harrison. 1982. High and low volume under-tree irrigation for citrus cold protection. Proc. Fla. State Hort. Soc. 95:23-26.

Gerber, J.F. 1970. Crop protection by heating, wind machines, and overhead irrigation. HortScience 5:427-431.

Harrison, D. S., A.G. Smajstrala, and F.S. Zazueta. 1983. An economic analysis of irrigation systems for production of citrus in Florida. Proc. Fla. State Hort. Soc. 96:7-11.

James, L.G. 1988. Principles of farm irrigation design. Wiley, New York. p. 158.

John, P. H., P. Carran, and I. Woodhead. 1986. Targeted frost protection-Field trials. New Zealand Agr. Eng. Inst. Project Rpt. 39. Lincoln College, Canterbury, New Zealand.

Parsons, L.R. and T.A. Wheaton. 1987. Microsprinkler irrigation for freeze protection: Evaporative cooling and extent of protection inan advective freeze. J. Amer. Soc. Hort. Sci. 112:897-902.

Rieger, M. 1989. Freeze protection for horticultural crops. Hort. Rev. 11:45-109.

Rieger, M., F.S. Davies, and L.K. Jackson. 1986. Microsprinkler irrigation and microclimate of young orange trees during freeze conditions. HortScience 21:1372-1374.

Rieger, M., G.H. Smerage, F.S. Davies, and L.K. Jackson. 1988. Modeling and simulation of tree wraps and microsprinkler irrigation for young citrus freeze protection: I. Model development and validation. J. Amer. Soc. Hort. Sci.

HORTSCIENCE 25(6):635-638. 1990.

\title{
Chilling Accumulation, Budbreak, and Fruit Set of Young Rabbiteye Blueberry Plants
}

\author{
Rebecca L. Darnell and Frederick S. Davies \\ Department of Fruit Crops, University of Florida, Gainesville, FL 32611
}

Additional index words. Vaccinium ashei, dormancy

Abstract. Potted 'Tifblue', Woodard', and 'Climax' rabbiteye blueberry plants (Vaccinium ashei Reade) were exposed to artificial or natural chilling regimes $(<7 \mathrm{C})$ ranging from 100 to 1000 hours during the dormant season to determine the effects on budbreak and fruit set. Insufficient chilling increased the days to $50 \%$ vegetative and floral budbreak in all three cultivars. The amount of floral budbreak increased in 'Tifblue' and 'Woodard', but decreased in 'Climax' as chilling increased. Insufficient chilling did not decrease percent fruit set of hand-pollinated flowers in any cultivar, indicating that the fruit-setting potential of these cultivars is unrelated to chilling.

The blueberry industry in the southeastern United States is based primarily on rabbiteye blueberries, which are native to the southeast and well adapted to the climate and mineral soils (Lyrene and Crocker, 1983). Rabbiteye blueberries are more vigorous and disease tolerant than highbush blueberries, which are also grown in the southeast; however, they generally have a much lower percent fruit set (Davies and Buchanan, 1979; El-Agamy et al., 1981; Lyrene and Crocker, 1983) and may not produce an adequate commercial crop.

Poor fruit set in rabbiteye blueberries is attributable to several factors, including cultivar (Davies and Buchanan, 1979; Lyrene and Goldy, 1983), pollen incompatibility (ElAgamy et al., 1981), presence and activity of bees (Davies and Buchanan, 1979; Payne et al., 1989), and proximity to pollenizers (Lyrene and Crocker, 1983). In addition, field observations (Lyrene and Crocker, 1983) suggest that insufficient chilling decreases frui set of rabbiteye blueberries. After mild winters, some rabbiteye cultivars bloom normally, but fail to set fruit adequately; also, percent fruit set improves from the southern to the northern end of the rabbiteye production area. Furthermore, there appears to be a positive correlation between yield and amount of chilling for some cultivars (Lyrene and Crocker, 1983). This relationship has led to the idea that insufficient chilling produces flowers with inherently less capacity to set fruit.

Insufficient chilling of blueberries and other

Received for publication 2 Feb. 1989. Univ. of Florida Journal Series no. R-00007. The cost of publishing this paper was defrayed in part by the payment of page charges. Under postal regulations, this paper therefore must be hereby marked advertisement solely to indicate this fact. deciduous fruit crops results in delayed and erratic budbreak (Amling and Amling, 1980; Gilreath and Buchanan, 1981; Spiers, 1976; Spiers and Draper, 1974) and delayed fruit development (Erez, 1987). However, there are no quantitative data to support the observations on chilling and fruit set of rabbiteye blueberries. The objective of this study was to determine the effects of dormant-season chilling on budbreak and subsequent fruit set of rabbiteye blueberry.

Outdoor experiment. Two-year-old dormant 'Woodard' and 'Tifblue' rabbiteye plant obtained from a commercial nursery were planted in 1 peat $: 1$ pine bark $(\mathrm{v} / \mathrm{v})$ in 11.4 liter plastic pots in early January. Twentyfive plants of each cultivar were grown outdoors under natural light and temperature conditions beginning 5 Jan. 1983. Plants had not been exposed to temperatures below 7C before that time. On $12 \mathrm{Jan}$. and every 2 weeks through 8 Mar., 10 plants (five of each cultivar) were randomly selected and moved into a greenhouse. Maximum/minimum greenhouse temperatures were $33 / 15 \mathrm{C}$ and photosynthetic photon flux (PPF) ranged from 300 to $1200 \mu \mathrm{mol} \cdot \mathrm{s}^{-1} \cdot \mathrm{m}^{-2}$. The number of hours below $7 \mathrm{C}$ for each group was recorded with a hygrothermograph. The number of chilling hours received by each group of plants was 134, 253, 320, 370, and 420, respectively.

Every 2 to 3 days during bloom, open flowers from each cultivar were tagged and cross-pollinated by hand using fresh pollen from the other compatible cultivar. Pollen was transferred with the thumbnail to the receptive stigma between 10:00 AM and noon, when greenhouse temperatures ranged from 20 to 27C. An average of 29 'Woodard' flowers/plant (range $=18$ to 37 ) and 36 'Tifblue' flowers/plant (range $=33$ to 41 ) were pollinated. Final fruit set percentage 